\title{
Review \\ Cofilin Signaling in the CNS Physiology and Neurodegeneration
}

\author{
Jannatun Nayem Namme ${ }^{1}$, Asim Kumar Bepari ${ }^{1, *}$ and Hirohide Takebayashi ${ }^{2, *}$ \\ 1 Department of Pharmaceutical Sciences, North South University, Dhaka 1229, Bangladesh; \\ jannatun.namme@northsouth.edu \\ 2 Division of Neurobiology and Anatomy, Graduate School of Medical and Dental Sciences, Niigata University, \\ Niigata 951-8510, Japan \\ * Correspondence: asim.bepari@northsouth.edu (A.K.B.); takebaya@med.niigata-u.ac.jp (H.T.)
}

Citation: Namme, J.N.; Bepari, A.K.; Takebayashi, H. Cofilin Signaling in the CNS Physiology and Neurodegeneration. Int. J. Mol. Sci. 2021, 22, 10727. https://doi.org/ 10.3390/ijms221910727

Academic Editor: Christina Piperi

Received: 10 August 2021

Accepted: 29 September 2021

Published: 3 October 2021

Publisher's Note: MDPI stays neutral with regard to jurisdictional claims in published maps and institutional affiliations.

Copyright: (c) 2021 by the authors. Licensee MDPI, Basel, Switzerland. This article is an open access article distributed under the terms and conditions of the Creative Commons Attribution (CC BY) license (https:// creativecommons.org/licenses/by/ $4.0 /)$.

\begin{abstract}
All eukaryotic cells are composed of the cytoskeleton, which plays crucial roles in coordinating diverse cellular functions such as cell division, morphology, migration, macromolecular stabilization, and protein trafficking. The cytoskeleton consists of microtubules, intermediate filaments, and actin filaments. Cofilin, an actin-depolymerizing protein, is indispensable for regulating actin dynamics in the central nervous system (CNS) development and function. Cofilin activities are spatiotemporally orchestrated by numerous extra- and intra-cellular factors. Phosphorylation at Ser-3 by kinases attenuate cofilin's actin-binding activity. In contrast, dephosphorylation at Ser-3 enhances cofilin-induced actin depolymerization. Cofilin functions are also modulated by various binding partners or reactive oxygen species. Although the mechanism of cofilin-mediated actin dynamics has been known for decades, recent research works are unveiling the profound impacts of cofilin dysregulation in neurodegenerative pathophysiology. For instance, oxidative stress-induced increase in cofilin dephosphorylation is linked to the accumulation of tau tangles and amyloid-beta plaques in Alzheimer's disease. In Parkinson's disease, cofilin activation by silencing its upstream kinases increases $\alpha$-synuclein-fibril entry into the cell. This review describes the molecular mechanism of cofilin-mediated actin dynamics and provides an overview of cofilin's importance in CNS physiology and pathophysiology.
\end{abstract}

Keywords: cofilin; cofilin-1; cytoskeleton; neurodegeneration; actin; neuron; Alzheimer's disease; schizophrenia; LIMK1; SSH1

\section{Introduction}

Neurons contain a cytoskeleton consisting of microtubules, neurofilaments, and actin filaments. Microtubules are composed of tubulin proteins and other polypeptides and provide the essential organization of organelles. Neurofilaments, which are class IV intermediate filaments, offer structural support to axons and influence nerve conduction velocity. Actin filaments (F-actin) are composed of globular actin monomers (G-actin). Dynamic transition can occur between G-actin and F-actin, and the polymerization-depolymerization events are spatiotemporally regulated in response to numerous extracellular and intracellular stimuli. Actin is an ATPase, and both G-actin and F-actin can bind to ATP. When ATP-bound G-actin monomers assemble into a polymer, ATP hydrolyzes rapidly to generate ADP-Pi actin, slowly releasing the inorganic phosphate producing ADP-actin subunits. Consequently, actin filaments exhibit considerable asymmetry with a plus end (barbed end or growing end) and a minus end (pointed end or shrinking end) dominated by ATP- and ADP-actins, respectively. ATP-G-actin monomers are preferentially polymerized to the barbed end whereas, ADP-actin subunits are depolymerized from the pointed end. The actin dynamics is precisely controlled by various actin-binding proteins (ABPs) such as actin-related protein 2/3 complex (Arp2/3), cortactin, formin, profilin, and actindepolymerizing factor (ADF)/cofilin (reviewed in [1]). 
Three ADF/cofilin family members are expressed in mammals: ADF, cofilin-1, and cofilin-2 (reviewed in [2,3]). The first member ADF (also known as destrin), encoded by the gene DSTN in humans, was initially identified in the chick brain [4]. Cofilin was discovered as an actin-interacting protein in the porcine brain $[5,6]$. Later, Ono et al. identified two mammalian variants of cofilin, non-muscle type (also known as cofilin-1 and n-cofilin) and muscle type (also known as cofilin-2 and m-cofilin) [7]. In humans, cofilin-1 and cofilin-2 are encoded by the genes CFL1 and CFL2, respectively. Different isoforms of ADF/cofilin have qualitatively similar but quantitatively different effects on actin dynamics [8]. To be noted, both ADF and cofilin show cooperative binding with actin filaments [9,10]. Interestingly, cofilin-1 comprises almost $90 \%$ of the total ADF/cofilin family in CNS [11]. For simplicity, we will use the term 'cofilin' to mention cofilin-1 hereafter.

Cofilin can bind to both G-actin and F-actin, exhibiting stronger affinities for the ADP-bound actins than the ATP- or ADP-Pi-bound forms [12]. Cofilin binding to F-actin induces actin subunit rotation, enhances Pi release along the filament, and promotes filament severing in a concentration-dependent manner $[8,13,14]$ (Figure 1). Severing is rapid at a low cofilin/actin ratio and suppressed at a high cofilin/actin ratio. Interestingly, only a few cofilin molecules can induce actin filament fragmentation, predominantly at the pointed end of the cofilin domain [15,16]. Severing generates newer ends of the filament where cofilin may accelerate the disassembly of ADP-actins from the pointed end [16]. On the contrary, higher cofilin concentrations can favor actin polymerization through nucleation [13]. Thus, cofilin is capable of controlling actin dynamics through both polymerization and depolymerization.

Conceivably, regulation of cofilin activity is immensely complex where diverse stimuli in the cell microenvironment orchestrate the cytoskeleton dynamics in physiological and pathophysiological conditions $[17,18]$. For instance, two guidance cues, nerve growth factor (NGF) and netrin-1, were found to activate cofilin, increase free actin barbed ends, and promote growth cone protrusion [19]. Meyer et al. (2005) showed that insulin-like growth factor I (IGF-I) enhances neuroblastoma cell motility through activation of cofilin and its upstream regulators [20]. Tilve and colleagues (2015) observed an extracellular synuclein-induced cofilin inactivation and dysregulation of neuronal actin dynamics [21]. At the molecular level, cofilin activity is modulated by phosphorylation-dephosphorylation, binding to other regulatory proteins, and redox modifications. We have discussed essential cofilin regulators in the next section. For further details, interested readers are referred to many outstanding reviews describing the roles and regulations of cofilin in actin dynamics [22-27]. 


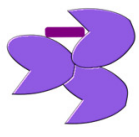

Nucleation

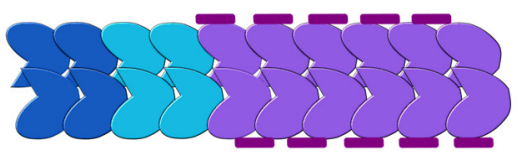

Stabilization

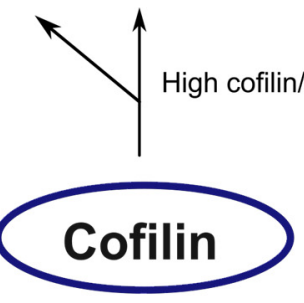

$\downarrow$

Low cofilin/actin ratios
Suppression of actin turnover

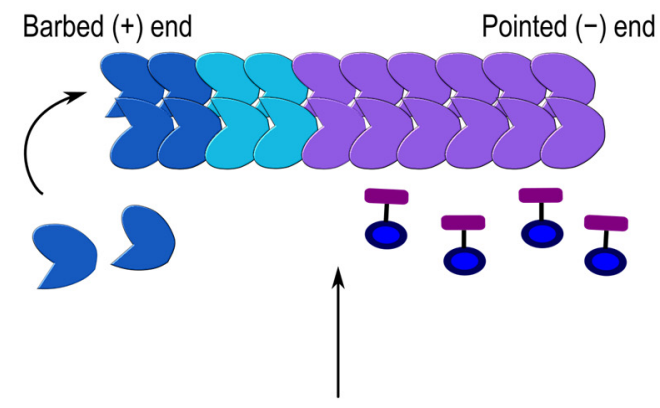

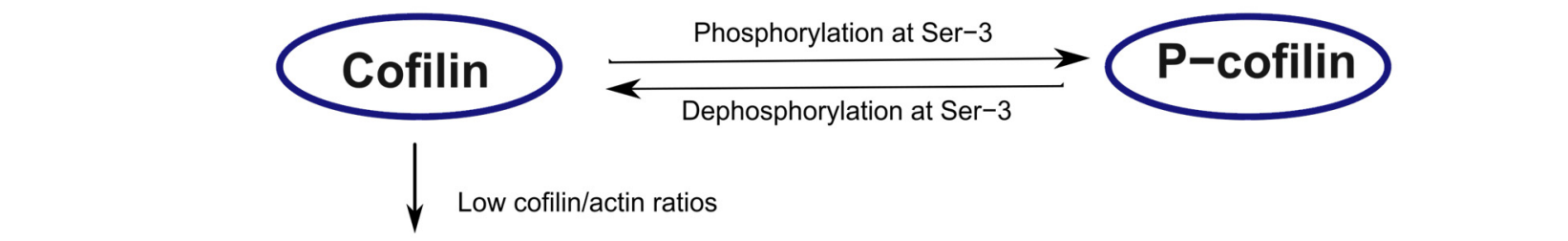

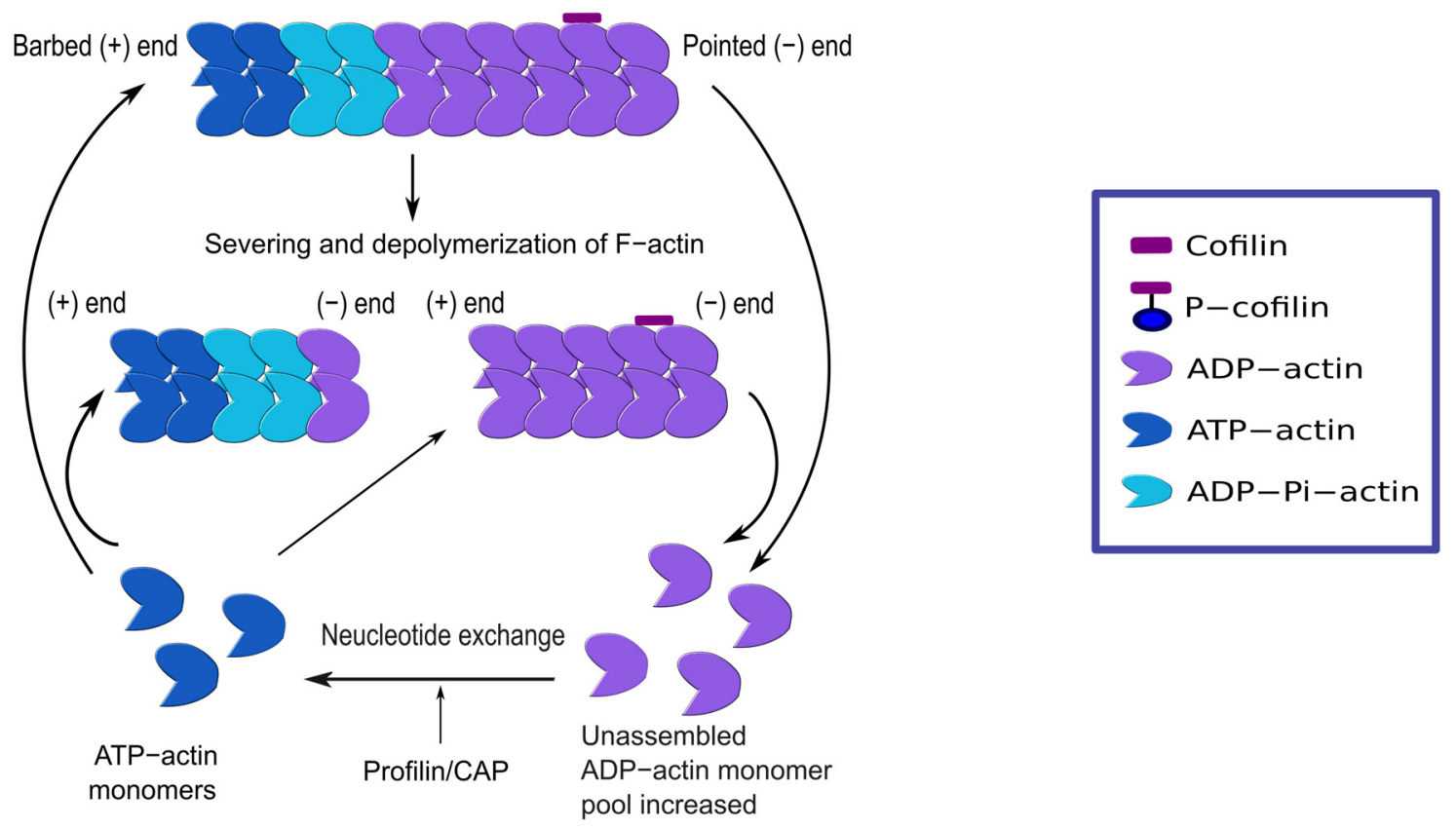

Promotion of actin turnover

Figure 1. Actin dynamics regulation by cofilin. At low cofilin/actin ratios, cofilin severs F-actin and increases the ADPactin monomer dissociation rate. Actin polymerization is favored in the presence of nucleotide exchange regulators (e.g., profilin, CAP). At high cofilin/actin ratios, cofilin stabilizes F-actin where all the subunits have undergone cofilin-induced rotation. Cofilin can also induce nucleation. Inactive p-cofilin does not significantly bind to F-actin, and actin severing or depolymerization is low.

\section{Signaling Mechanisms for Cofilin Activation and Inactivation}

The Ser-3 residue in cofilin is a conserved phosphorylation site [28,29]. Cofilin is activated via dephosphorylation at Ser-3 by slingshot family proteins (SSHs; SSH1, SSH2, and SSH3) through the $\mathrm{Ca}^{2+} /$ calmodulin-dependent calcineurin activation pathway $[30,31]$. On the other hand, cofilin is deactivated via phosphorylation at Ser-3 by LIM domain kinases (LIMKs) and dual-specificity testis-specific protein kinases (TESKs) [32,33]. Major proteins modulating cofilin activity are listed in Table 1, and critical signaling mechanisms are summarized in Figure 2. 
Table 1. Short overview of the functional modulators of cofilin.

\begin{tabular}{|c|c|c|c|c|}
\hline Enzymes & Gene Name & $\begin{array}{c}\text { Isoforms/Alternative } \\
\text { Names }\end{array}$ & Roles in Cofilin Regulation Pathway & References \\
\hline Slingshot phosphatase & SSH & $\begin{array}{l}\text { SSH1 } \\
\text { SSH2 } \\
\text { SSH3 }\end{array}$ & $\begin{array}{l}\text { Dephosphorylate cofilin; } \\
\text { dephosphorylate coronins }\end{array}$ & {$[31,34]$} \\
\hline Coronins & $\mathrm{CORO}$ & $\begin{array}{l}\text { Coronin } 1 \mathrm{~A} \\
\text { Coronin } 1 \mathrm{~B} \\
\text { Coronin } 2 \mathrm{~A}\end{array}$ & $\begin{array}{c}\text { Induce cofilin activation via SSH1 } \\
\text { dephosphorylation, } \\
\text { Interact with 14-3-3zeta protein }\end{array}$ & {$[35,36]$} \\
\hline 14-3-3zeta protein & YWHAZ & $\begin{array}{l}\text { Protein kinase } C \\
\text { inhibitor protein } 1 \\
\quad(\mathrm{KCIP}-1)\end{array}$ & $\begin{array}{l}\text { Downregulates cofilin activity via SSH1 } \\
\text { deactivation and LIMK activation }\end{array}$ & {$[37,38]$} \\
\hline $\begin{array}{l}\text { Protein kinase D } \\
\text { enzymes (PKDs) }\end{array}$ & $P R K D$ & $\begin{array}{l}\text { PKD1 } \\
\text { PKD2 } \\
\text { PKD3 }\end{array}$ & $\begin{array}{l}\text { Decrease cofilin dephosphorylation by } \\
\text { promote 14-3-3zeta protein binding with } \\
\text { SSH1 and by inducing LIMK1 activation }\end{array}$ & [39] \\
\hline Chronophin (CIN) & PDXP & $\begin{array}{l}\text { Pyridoxal phosphate } \\
\text { phosphatase }\end{array}$ & $\begin{array}{l}\text { Interacts and inhibits Hsp90-mediated } \\
\text { LIMK activation, hence induce } \\
\text { cofilin phosphorylation }\end{array}$ & {$[40,41]$} \\
\hline LIM kinases & LIMK & $\begin{array}{l}\text { LIMK1 } \\
\text { LIMK2 }\end{array}$ & Phosphorylate and inactivate cofilin & {$[42,43]$} \\
\hline TES kinases & TESK & $\begin{array}{l}\text { TESK1 } \\
\text { TESK2 }\end{array}$ & Phosphorylate and inactivate cofilin & {$[44,45]$} \\
\hline Reelin & RELN & $\begin{array}{l}\text { Isoform } 1 \\
\text { Isoform } 2 \\
\text { Isoform } 3\end{array}$ & $\begin{array}{l}\text { Increase cofilin phosphorylation by } \\
\text { inducing LIMK1 activation }\end{array}$ & {$[46,47]$} \\
\hline $\begin{array}{l}\text { SH3 protein interacting } \\
\text { with Nck, } 90 \text { kDa (SPIN90) }\end{array}$ & KCKIPSD & $\begin{array}{l}54 \mathrm{kDa} \\
\text { vimentin-interacting } \\
\text { protein } \\
\text { (VIP54) }\end{array}$ & Inhibits cofilin activity by binding & [48] \\
\hline Cortactin & CTTN & $\begin{array}{c}\text { Amplaxin; } \\
\text { oncogene EMS1 }\end{array}$ & $\begin{array}{l}\text { Downregulates cofilin activity } \\
\text { by binding }\end{array}$ & [49] \\
\hline $\begin{array}{c}\text { Adenylyl cyclase- } \\
\text { associated proteins (CAPs) }\end{array}$ & $C A P$ & $\begin{array}{l}\text { CAP1 } \\
\text { CAP2 }\end{array}$ & $\begin{array}{l}\text { Enhance cofilin activity by synergizing } \\
\text { cofilin activity }\end{array}$ & [50] \\
\hline
\end{tabular}

Though all three mammalian SSHs have cofilin phosphatase activity, SSH1 is the most effective in activating cofilin [30]. The N-terminal domain of SSH1 interacts with cofilin, where the Cys-393 residue of SSH1 is critical in removing the phosphate group from cofilin Ser-3 [51,52]. SSH1 can also dephosphorylate LIMK1 and attenuate LIMK1's enzymatic activity towards cofilin [53]. Singla et al. (2019) showed that growth factor induction in macrophages can activate cofilin and regulate actin dynamics through an SSH1-dependent pathway [54]. In addition, SSH1 has independent F-actin-stabilizing and bundling activities and promotes the disassembly of F-actin [34].

Coronins are F-actin-binding proteins, which also interact with microtubules and modulate cell motility and actin dynamics. SSH1 can dephosphorylate Coronins. Inversely, coronins may dephosphorylate SSH1 and induce cofilin activation at the leading edge $[35,36]$. Coronin-1B directs SSH1 towards lamellipodia and thereby regulates the activity of cofilin via dephosphorylation [35]. Coronin-2A binds and colocalizes with SSH1 at focal adhesions [36]. Depletion of coronin-1B inhibits SSH1-induced lamellipodial dynamics and cofilin activation, while coronin-2A depletion increases the p-cofilin level and diminishes cell migration and focal adhesion. Coronin-2A depletion can be rescued by expressing active cofilin in cell-free assays and cultured cells [36]. 


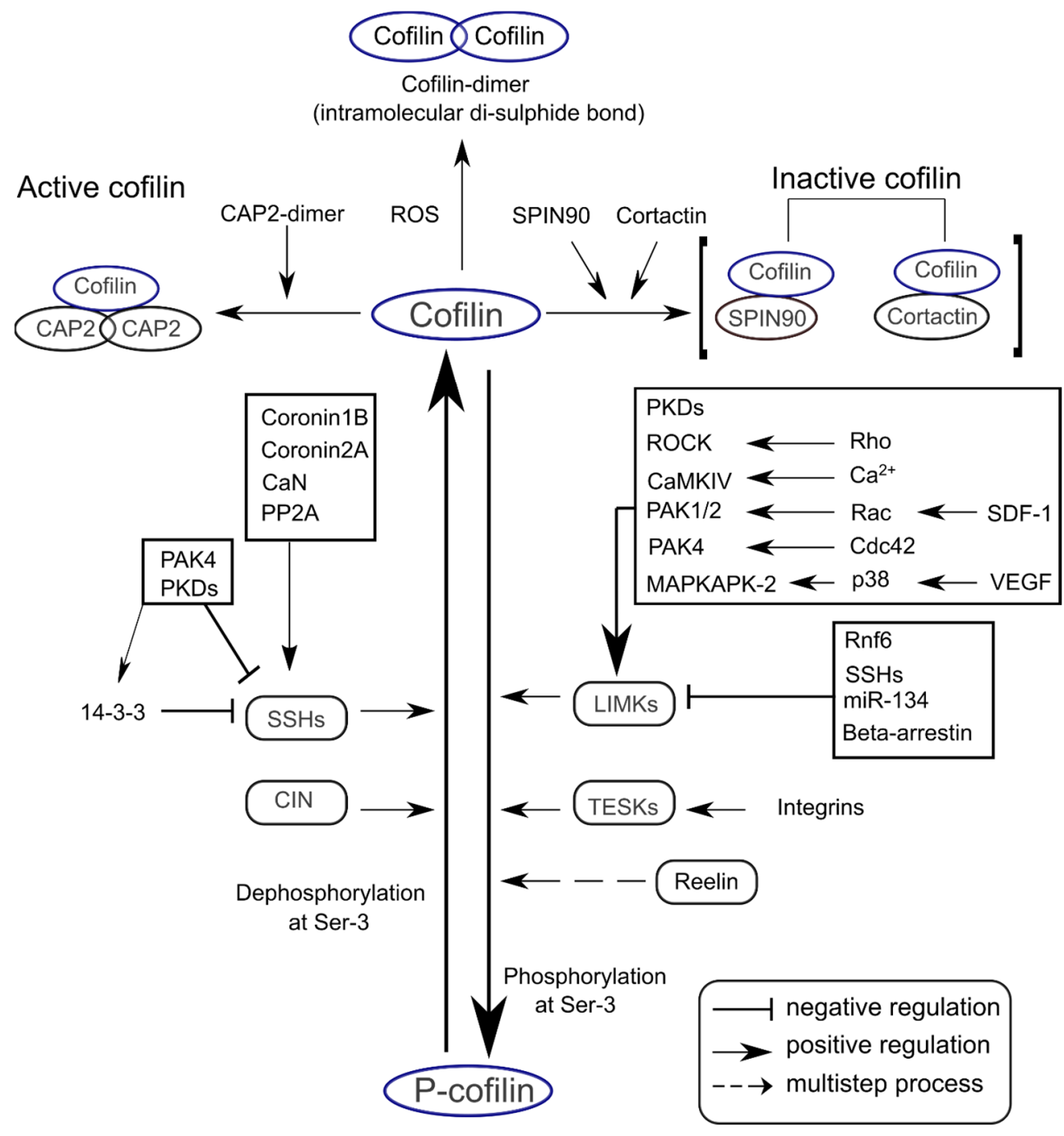

Figure 2. Signaling mechanisms regulating cofilin activity in the CNS. Cofilin can be dephosphorylated at the Ser-3 residue by SSHs and CIN. Cofilin Ser-3 phosphorylation is mediated by LIMKs and TESKs. These phosphatases and kinases can be activated or inhibited by diverse upstream regulators. Cofilin activity is enhanced through binding with CAP2 dimers (upper left), while binding with SPIN90 or cortactin decreases cofilin activity (upper right).

LIM-kinases are actin-binding proteins, which phosphorylate cofilin specifically at Ser3 , attenuating the actin-binding, severing, and depolymerizing activities of cofilin [32,33], reviewed in [24]. LIMK1 inactivates cofilin under control of ras-related C3 botulinum toxin substrate 1 (Rac1), while LIMK2 phosphorylates cofilin in response to Rho and Cell Division Cycle 42 (Cdc42) rather than Rac1 [42,55]. Downregulation of LIMK1 suppresses the lamellipodium formation induced by Rac1 or insulin. Therefore, both LIMK1 and LIMK2 phosphorylate cofilin through the Rac1/PAK and Rho/Cdc42 pathways, respectively.

TESKs are structurally related to LIM-kinases with a kinase domain and a unique C-terminal proline-rich domain. TESK1 can phosphorylate cofilin at Ser-3 in vitro and in vivo to affect actin organization [44]. When active cofilin was expressed in HeLa cells, rhodamine-phalloidin (a conjugate dye used to stabilize actin filaments in vitro) staining was markedly decreased by cofilin-mediated actin depolymerization, and this phenomenon was reversed by co-expression of TESK1 with cofilin [56]. Using TESK1 knockout mice, Wang et al. (2018) showed that TESK1 kinase activity is critical in cofilin-induced actin depolymerization [57]. TESK2 was also found to mediate cofilin phosphorylation and the formation of actin stress fibers in cultured cells [45].

CAPs are multi-domain actin-binding proteins having the capability of actin dynamics regulation at multiple levels [58]. CAPs and cofilin synergize to enhance depolymerization 
of F-actin at the pointed end [50]. CAPs compete with cofilin to bind with G-actin and promote its nucleotide exchange. Though two homologs of CAPs, CAP1 and CAP2, have been described in mammals, in humans, CAP2 plays a crucial role in neuronal cells, most notably in spine morphology [59]. CAP2 dimers/oligomers promote depolymerization of cofilin-saturated fragments of F-actin [50,58]. Alterations in dendritic architecture and spine morphology have been reported in CAP2 knockout neurons [60]. A recent study reported CAP2 as a postsynaptic protein relevant to regulating synaptic transmission and plasticity by shaping dendritic and spine morphology, which are all interconnected to actin depolymerization through cofilin activity [60].

In addition to phosphorylation-dephosphorylation, cofilin activity is also altered by several other mechanisms, including redox regulation. ROS can directly modulate cofilin in two different ways. First, direct oxidation of cofilin at Cys-139/147 to sulfenic acid in response to hydrogen peroxide $\left(\mathrm{H}_{2} \mathrm{O}_{2}\right)$ impairs cofilin binding to actin [61]. Second, under mild oxidative stress, ROS induces cofilin activation and an intermolecular disulfide bond between Cys-147 and Cys-39, forming cofilin-actin oligomers [62,63] and may lead to rod formation under an oxidative environment. Nonetheless, ROS can modulate cofilin by oxidation and inhibiting its actin-severing action.

\section{Cofilin Functions in the CNS Development}

\subsection{Neural Tube Morphogenesis}

Neurulation in human embryos proceeds in two phases, primary and secondary. The neural tube, the embryonic precursor of the CNS, is developed from the neural plate (a section of the ectoderm) via primary neurulation [64] involving four overlapping stages: neural induction, shaping, bending of the neural plate, and neural tube closure [65]. Neural crest cells are generated from the neural tube during neurulation and take long migration routes before settling and differentiating into distinct cell types. Gurniak et al. (2005) showed that the cofilin-mutant mouse embryos fail to form the neural tube and exhibit substantial aberration migration of neural crest cells [66]. Cofilin mutation results in malformation of actin structure and loss of polarity of the neural crest cells, which severely affects neuronal development in mice [66]. Cofilin is indispensable for actin depolymerization and actomyosin organization in the neural epithelium, which are critical for neural tube formation $[67,68]$. A lack of secretory pathway calcium ATPase (SPCA1) in mouse embryos shares similar neural tube deformation with cofilin mutants [69]. Interestingly, SPCA1 was found to direct cofilin colocalization with apical actin filaments in the neuroepithelium. Thus, cofilin appears as an essential protein for proper neural tube closure during embryonic development.

\subsection{Neurite Formation}

The formation of neurites, the immature projections arising from the neuronal cell body, is a unique and significant step in neurogenesis. The brain's development and function largely depend on neurite formation, which requires many growth signals, receptor stimuli, and a complex interplay among intracellular and extracellular signals. Actin can function as a microtubule entry barrier in dendritic spines and guide microtubules growing into filopodia [70]. Penetration of microtubules is determined by an adequate balance between forward polymerization and backward transport by the retrograde flow of lamellipodium actin [71]. Three steps are involved in axon elongation: protrusion, engorgement, and consolidation. In protrusion, F-actin's polymerization triggers elongation of lamellipodia and filopodia, whereas F-actin depolymerization guides polymerized microtubules to elongate into the peripheral domain. In the consolidation step, the transition of microtubules from polymerization to stabilization enables the formation of the neurite shaft. Repeated cycles of these three steps lead to axon elongation. Again, the growth cone's lamellipodial extension and filopodial retraction are necessary for all three axon elongation stages [71]. Cofilin is highly concentrated in dendritic spines and growth cones of neurons [72]. It controls the number and length of filopodia in response to brain-derived 
neurotrophic factor (BDNF) [73]. At the rear of actin meshwork in the growth cone, cofilin promotes actin monomers' recycling to the leading edge for assembly. Cofilin thereby enhances membrane protrusion by altering interactions of F-actin with microtubules [74]. Cofilin also facilitates bundling and penetration of microtubules into the growth cone and restricts microtubule entry into dendritic spines.

Furthermore, several proteins such as neuronal Nogo-A, semaphorin 3A, and BDNF have been found to regulate the growth cone through cofilin $[74,75]$. Overexpression of cofilin or its phosphorylation-resistant mutant cofilin S3A (active cofilin mutant) can stimulate more growth cone-like waves, which produce significantly longer axons. In contrast, the inactivation of cofilin by LIMK1 overexpression disrupts the fan-like structure of the growth cone, perturbing axon elongation and growth cone motility [76,77]. Such defects can be recovered by overexpressing S3A or slingshot homolog (SSH), a protein phosphatase [51]. Enhancement of actin filament turnover in vivo is critically regulated by cofilin during neurite formation. Cofilin knockout mice exhibit severe abnormalities in multiple brain regions resulting from a profound retrograde flow reduction [76].

\subsection{Synaptic Plasticity}

Long-term potentiation (LTP) and long-term depression (LTD) render durable synaptic plasticity essential for learning and memory. For long-term plasticity, actin-dependent cytoskeletal changes are pivotal in mediating qualitative and quantitative alterations of dendritic spines and synapses (reviewed in [78]).

LTP induction in dendritic spines accompanies spine enlargement and translocation of cofilin to spines [79]. In the LTP, dendritic spine upregulation depends on cofilin phosphorylation, while spine downregulation in the LTD relies on $\mathrm{Ca}^{2+}$-dependent calcineurininduced cofilin dephosphorylation [80]. Cofilin is co-localized with CAP2 dimers in the postsynaptic spine, which are required for actin turnover regulation [60]. Functional loss of cofilin causes aberrant spine enlargement, while overaction of cofilin increases actin depolymerization, leading to spine shrinkage or immature spine formation [81-83]. Synaptic relocation of AMPA receptors (AMPARs) is crucial for both LTP and LTD [84]. Cofilin has been found to mediate actin dynamics in postsynaptic trafficking of AMPARs following LTP induction [81]. Moreover, the mobility of AMPARs requires cofilin activity during memory extinction, where phosphorylation of cofilin causes impairment in memory extinction [85]. Therefore, optimum cofilin activity is essential to mediate structural and functional changes in synaptic plasticity.

\subsection{Axon Regeneration}

Axonal distortion following external or internal injury or inflammation in the CNS ensues neurodegeneration. Ironically, a failed regeneration of injured axons in the adult CNS is contrasted with the vigorous axonal growth during embryonic development. Regeneration failure is associated with extracellular inhibitory factors and downregulation of neuron-intrinsic regenerative programs (reviewed in [86,87]). Unlike the developing neurons, injured CNS neurons do not display growth cones following axon injury [88]; instead, dystrophic bulbs called 'retraction bulbs' are generated (Figure 3).

Stern et al. (2013) studied regeneration events in a mouse nerve injury model where facial axotomy induced nuclear localization of cofilin [89]. Interestingly, activating injured neurons with serum response factor (SRF) enhanced neurite formation and growth cone structures with concomitant depletion of cofilin's nuclear translocation. Citron kinase (citron-K) is an inhibitor of neuronal regeneration [90]. Knockdown of citron-K increased cofilin levels in rat dorsal root ganglion (DRG) cultures treated with CNS myelin extract and fibroblast growth factor-2 (FGF2). It attenuated neurite outgrowth inhibition of DRG neurons [90]. Tedeschi et al. (2019) showed that nerve conditioning lesions in rodents induce rapid actin turnover and growth cone regeneration in both the PNS and CNS [91]. Conditioning enhanced SSH1 activity and reduced p-cofilin levels, which accompanied a significant increase in the number of growth cone protrusions and filopodia. Intriguingly, 
conditioning-induced axon regeneration was dependent on the actin severing activity, but not on the depolymerization activity of cofilin [91]. In addition, both actin reorganization and axon regeneration were seen to be abolished in cofilin-deficient neurons after spinal cord injury [91]. Therefore, accumulating evidence positions cofilin as a potential molecular target for CNS axon regeneration.

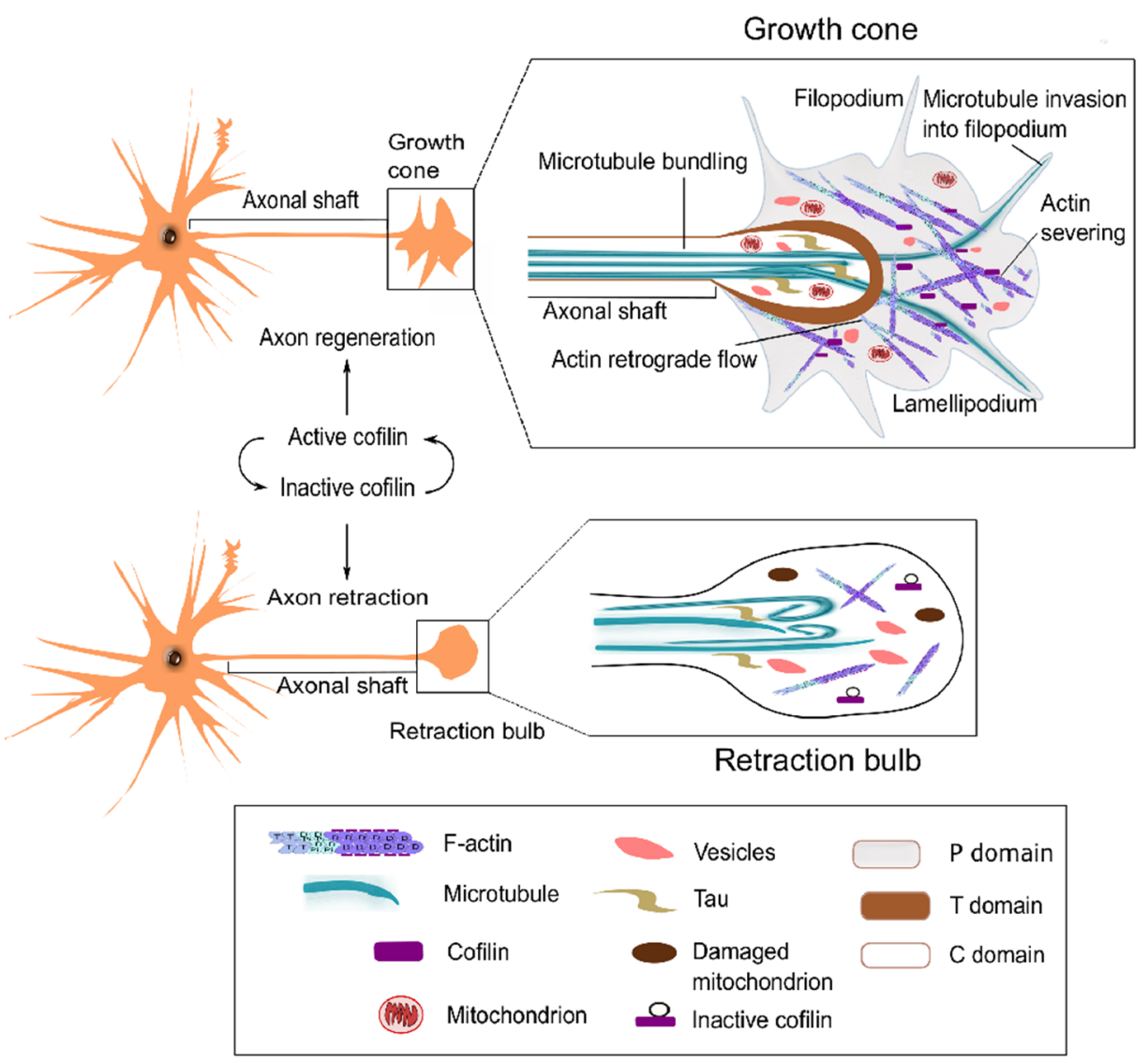

Figure 3. Roles of cofilin in growth cone motility for axonal development. Active cofilin enhances growth cone formation by promoting actin turnover during development and regeneration. Cofilin inactivation suppresses actin turnover, which hinders growth cone development and may cause axonal retraction.

\section{Cofilin Dysregulation and Neurodegenerative and Psychiatric Disorders}

Since cofilin is an essential regulator of cytoskeletal and neuronal functions, disruption of its structure and function has profound implications in several neurological disorders (Figure 4). Cofilin dysregulation in rodent models exhibited many neurological symptoms, including cognitive impairment, memory dysfunction, and sleep deprivation [92]. On the other hand, excess phosphorylation of cofilin can induce dendrite reduction and neurodegeneration in Alzheimer's disease (AD) and schizophrenia [93]. 


\section{Parkinson's disease}

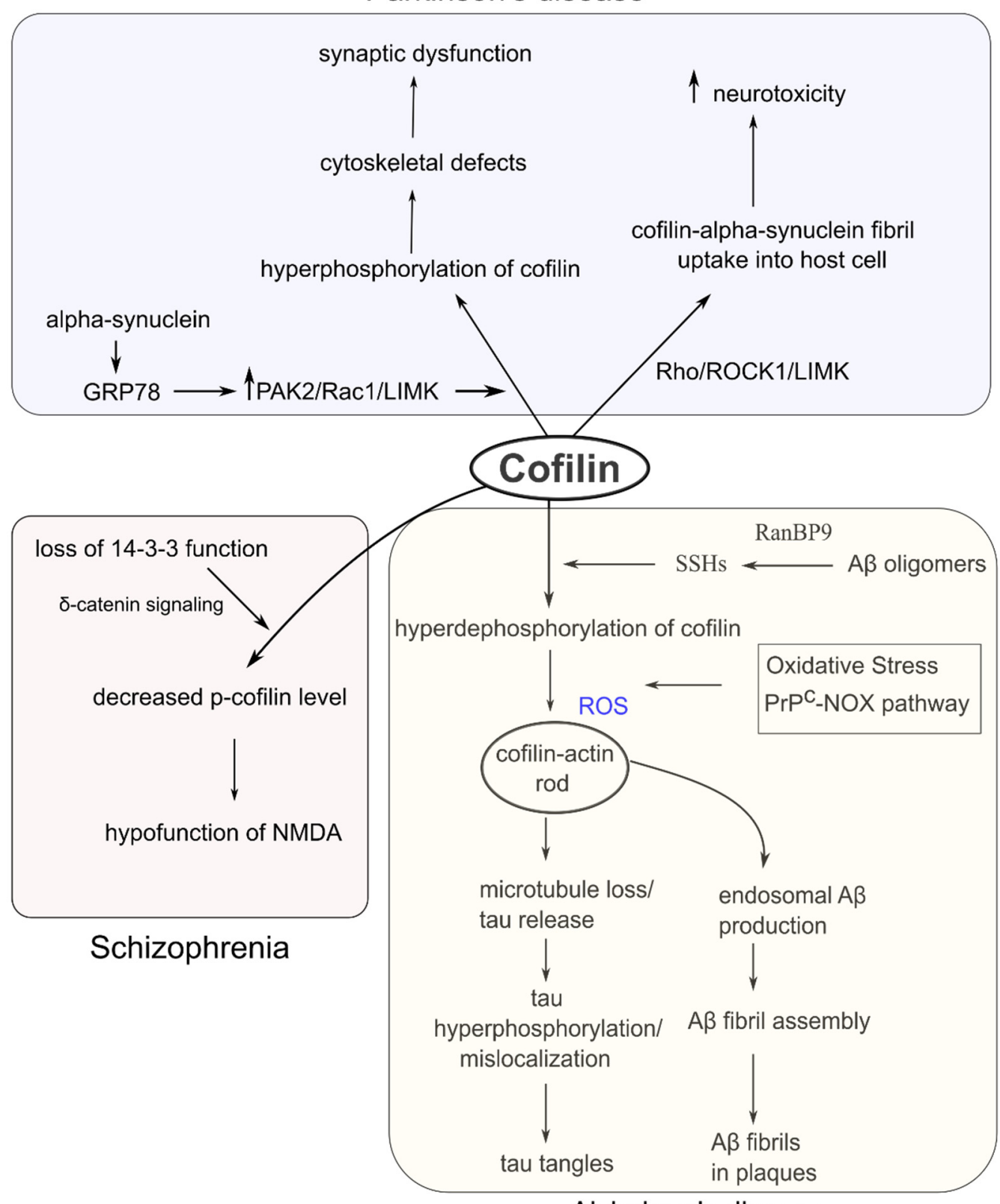

Alzheimer's disease

Figure 4. Dysregulation of cofilin in neurodegenerative and psychiatric disorders. Upper (cofilin dysfunction in PD): Alphasynuclein can induce cofilin hyperphosphorylation leading to synaptic aberration. Alpha-synuclein can also interact with cofilin to form cofilin-alpha-synuclein fibrils and enhance neurotoxicity. Lower left (cofilin dysfunction in schizophrenia): Functional loss of 14-3-3 decreases the p-cofilin level and NMDA function. Lower right (cofilin dysfunction in AD): A $\beta$ oligomers can activate SSHs and induce cofilin hyperdephosphorylation, which enhances cofilin-actin rod formation in the presence of excess ROS. Cofilin-actin rods can further accelerate the formation of tau tangles and A $\beta$ plaques.

\subsection{Alzheimer's Disease (AD)}

$\mathrm{AD}$ is a chronic neurodegenerative disease that starts slowly and worsens gradually over time. The most common symptoms are associated with signs of dementia and behavioral disorders. Both familial and sporadic AD types can be induced by diverse factors such as aging, oxidative stress, neuroinflammation, and synaptic disruption [94,95]. The two most common pathophysiologic hallmarks of AD are (1) deposition of extracellular beta-amyloid (A $\beta$ ) (in senile plaques) and (2) phospho-tau containing intracellular neurofibrillary tangles "tau tangles" (paired helical filaments) (reviewed in [96,97]). 
An appearance of amyloid-beta $(A \beta)$ - and tau-dependent spine loss is a pathologic feature that directly correlates with cognitive declines in $\mathrm{AD}$ [98]. Cofilin was found to aggregate with $\mathrm{A} \beta$ oligomers in human $\mathrm{AD}$ brain tissues and mouse AD models [11,99]. $\mathrm{A} \beta$ interacts with many synaptic proteins such as NMDA receptors, $\operatorname{PrP}^{\mathrm{C}}$ (prion protein), ephrin type B-2 receptor (EphB2), metabotropic glutamate receptor 5 (mGluR5), and $\beta$-integrin [100]. Woo et al. (2015) showed, using both cultured neurons and in vivo mouse models, that the ran-binding protein 9 (RanBP9) can mediate the accumulation of cofilin-actin rods [101]. RanBP9 enhanced the $\operatorname{PrP}^{\mathrm{C}}$-dependent $\mathrm{A} \beta$ - $\beta 1$-integrin signal and cofilin dephosphorylation by SSHs. The RanBP9-SSH1-cofilin axis promoted cofilin translocation in the mitochondria and induced a cofilin-actin pathology leading to synaptic and mitochondrial dysfunction $[101,102]$. Decreased cofilin expression by downregulation of RanBP9 resulted in protection from memory and learning defects in a mouse model of contextual fear conditioning, signifying roles of cofilin activity levels in hippocampal learning and memory [101].

Cofilin activation in cultured neurons induced cofilin-rod formation, transforming phosphorylated microtubule-associated protein tau (MAPT) into cytoskeletal inclusions [103]. In Tau-P301S mice, active cofilin was found to promote tauopathy by specific inhibition of the tau-microtubule interaction through direct competition with tau $[104,105]$. Moreover, synaptic dysfunction in tau-P301S hippocampal neurons was rescued through genetic ablation of cofilin [104]. In the tau-P301S tauopathy mice, chronic administration of LM11A-31, a small-molecule ligand for p75 neurotrophin receptor (p75NTR), prevented activation of c-Jun N-terminal kinase (JNK) pathway and normalized cofilin phosphorylation at Ser-3 [106]. Notably, LM11A-31 lessened the dendritic spine degeneration and improved hippocampal behaviors, suggesting cofilin association in tauopathies [106].

Decreased CAP2 and increased cofilin levels were reported in hippocampal postsynaptic fractions in an AD mouse model [107]. Small hairpin RNA (shRNA)-mediated down-regulation of CAP2 altered dendritic and spine morphologies in cultured neurons. Additionally, induction of LTP in rat hippocampal neurons augmented CAP2 dimerization and CAP2-cofilin association. This study also found a decreased hippocampal CAP2 protein level and a reduction in the ratio of CAP2/cofilin in AD patients compared to healthy controls, implicating CAPs in AD pathophysiology [107].

\subsection{Schizophrenia}

Schizophrenia is a complex neuropsychiatric disorder with diverse symptoms, including hallucination, delusions, restricted emotion, and other cognitive impairments affecting memory, attention, and executive functions (review [108,109]). Synaptic dysfunctions such as altered synaptic plasticity and synapse formation have been reported in schizophrenia $[110,111]$. Schizophrenia has been genetically associated with the opioid binding protein/cell adhesion molecule (OPCML), which is abundantly expressed in CNS, especially in the hippocampus and cerebral cortex [112]. OPCML polymorphisms showed association with risks to schizophrenia and some other psychiatric disorders [113]. Opcml-deficient $\left(\mathrm{Opcml}^{-/-}\right)$mice also displayed abnormal sensorimotor gating and impaired cognitive behaviors similar to schizophrenia [114]. OPCML was found to interact with EphB2 and control spine stability by regulating the ephrin-EphB2-cofilin signaling pathway. Notably, a pharmacologic intervention with aripiprazole administration restored the abnormal behaviors in $\mathrm{Opml}^{-/-}$mice by increasing p-cofilin and facilitating spine maturation [114]. This report suggests that decreased phosphorylation of cofilin might be involved in schizophrenia pathophysiology.

Another study reported that functional inhibition of 14-3-3 protein in neurons in the mouse nervous system lead to behavioral deficits corresponding to the core symptoms of schizophrenia [115]. A low level of phosphorylated cofilin and NMDA hypofunction were observed in the mutant mice, suggesting that disruption of the 14-3-3 protein function might cause schizophrenia symptoms through an aberration of actin dynamics. The authors suggested that the 14-3-3 protein indirectly regulates p-cofilin level through the 
$\delta$-catenin signaling pathway rather than altering $\mathrm{p}$-cofilin through a direct protein-protein interaction [115].

\subsection{Ischemic and Hemorrhagic Stroke}

Immediately after ischemic stroke, neuronal cell death occurs rapidly due to initial loss of blood flow, increased oxidative stress by an overload of cytosolic $\mathrm{Ca}^{2+}$, increased excitotoxicity, lack of oxygen, and glucose. Overload of $\mathrm{Ca}^{2+}$ activates NADPH-oxidase (NOX) through PKC and nitric oxide (NO), leading to a high level of glutamate accumulation in extracellular space (reviewed in $[116,117])$. Glutamate causes excitotoxicity at higher doses by overstimulating NMDA, AMPA receptors, $\mathrm{Ca}^{2+}$ overload, and mitochondrial dysfunction [118]. Several studies reported that both non-NMDA and NMDA receptors can stimulate glutamate-induced cofilin dephosphorylation and rod formation [119-121]. During excitotoxic neuronal death, NMDARs stimulation promotes cofilin dephosphorylation by the $\mathrm{Ca}^{2+}$-SSH1-cofilin pathway in cortical neurons where cofilin physiologically remains phosphorylated. NMDA-induced cofilin dephosphorylation enhances cofilin translocation in mitochondria and decreases p-cofilin level in the cytosol. Cofilin contributes to the translocation of Bax into mitochondria. [122], promoting mitochondrial membrane depolarization and releasing apoptotic factors like cytochrome C. Acute knockdown of cofilin or SSH1 exhibited a marked neuroprotective action on NMDA-mediated neuronal death [122]. Another recent study demonstrated that rod-induced microtubule-associated protein-2 (MAP2) degradation and cofilin-mediated apoptosis are reduced if cofilin is inhibited by LIMK1 overexpression in the infarct cortex after stroke [123].

Moreover, cofilin oxidation may lead to oxidant-induced apoptosis [124]. Ischemic and hemorrhagic stroke-induced oxidative stress might be a consequence of ROS-induced cofilin oxidation, which translocates free cofilin into the mitochondria, thereby initiates cytochrome $\mathrm{C}$ release leading to apoptosis [125]. During the acute phase of ischemic injury and the initial phase of secondary injury to intracranial hemorrhage (ICH), inhibition of elevated cofilin activation in the extracellular region either using pharmacological inhibitor or via phosphorylation could diminish excitotoxicity-induced neuronal death (reviewed in [126]).

Using a rat stroke model, Shu et al. (2019) suggested that rod formation disrupts dendritic mitochondrial trafficking during ischemic conditions [120]. Accumulation of rods induced impaired synaptic structure and blockade of dendritic trafficking in the brain, whereas elevation of p-cofilin level successfully inhibited rod formation and rescued synaptic structure [120].

Pharmacological induction of the $70 \mathrm{kDa}$ heat shock protein (HSP70) has been suggested as a potential therapeutic intervention for stroke [127]. The HSP70-deficient mice exhibited an increased cofilin-actin rod and a larger lesion size in the ischemic border zone. In contrast, HSP70 overexpression in transgenic mice reduced rod formation and improved neurological symptoms following stroke [128]. These reports indicate that cofilin is necessary during the recovery phase of stroke, and perturbed cofilin activity during this period might negatively affect the regenerative process. Therefore, rod suppression via cofilin modulation could emerge as an efficacious treatment approach for ischemic stroke.

\subsection{Parkinson's Disease (PD)}

$\mathrm{PD}$ is another age-related neurodegenerative disorder characterized by the dopaminergic neuron loss in the substantia nigra and by the presence of Lewy neurites (LNs) and Lewy bodies (LBs) in cortical and subcortical neurons [129]. A significant component of LBs and LNs is the misfolded alpha-synuclein ( $\alpha$-synuclein), a conventional protein widely distributed in CNS, mainly in the presynaptic nerve terminals [130]. It has been suggested that $\alpha$-synuclein exerts its pathologic function in a cell-autonomous manner in the neuronal cytoplasm and may amplify and propagate PD-related pathology [131].

Extracellular $\alpha$-synucleins upregulate surface-exposed glucose-related protein of $78 \mathrm{kDa}$ (GRP78, an endoplasmic reticulum chaperone) that becomes clustered into mi- 
crodomains of the neuronal plasma membrane [132]. Interaction of $\alpha$-synucleins and GRP78 activates a signaling cascade, which could phosphorylate/inactivate cofilin and promote actin stabilization and stress fibers formation. Downregulation of GRP78 abolishes $\alpha$ synuclein-driven cofilin phosphorylation and actin stabilization. Alpha-synuclein has also been correlated with PAK2 and Rac1 phosphorylation, which mediates cofilin phosphorylation via LIMK, implicating the Rac1/PAK2/LIMK/cofilin pathway in $\alpha$-synuclein-induced actin-alteration [132]. Interestingly, $\alpha$-synuclein-induced cytoskeletal-associated defects in axonal development could be prevented by cofilin activation in cultured hippocampal neurons [21].

The pathological $\alpha$-synuclein-fibrils are transmitted from the fibril-generating cells to recipient cells and spread throughout the brain. Cofilin was found to facilitate the $\alpha$ synuclein-fibril uptake into recipient cells and the expansion of $\alpha$-synuclein pathology [133]. The combined fibrils consisting of $\alpha$-synuclein and cofilin are more compact and more potent than aggregated $\alpha$-synuclein-fibril. Though the underlying mechanism of cofilin- $\alpha$ synuclein-fibril interaction is unknown, it is deducible that in the presence of $\alpha$-synucleinfibrils, cofilin may alter the membrane barrier by depolymerizing actin and form vesicles to promote endocytosis [133]. Upregulation of cofilin by silencing ROCK1 and Rho was found to increase $\alpha$-synuclein-fibril entry, whereas cofilin downregulation decreased the $\alpha$ synuclein-fibril entry into the cell [134]. The authors suggested that the Rho-ROCK1-LIMKcofilin signaling pathway triggers $\alpha$-synuclein-fibril uptake into the host cells, and the pathogenic impact of $\alpha$-synuclein in the actin cytoskeleton proceeds through cofilin [134].

Mutations of the parkin (PARK2) gene have been linked to autosomal recessive juvenile parkinsonism and early-onset parkinsonism $[135,136]$. Lim et al. provided evidence on functional interaction between parkin and LIMK1 in human dopaminergic neuroblastomaderived BE(2)-M17 cell line, where parkin overexpression enhances LIMK1-ubiquitination and reduces the level of LIMK1-induced cofilin phosphorylation [137]. Further research would be necessary to substantiate the roles of cofilin in the pathophysiology of earlyonset PD.

\section{Conclusions}

The findings generated from a plethora of studies implicate that proper balance in cofilin activity is a prerequisite for actin turnover and CNS functions. Among various regulatory pathways already discovered for cofilin, phosphoregulation through SSHs and LIMKs is the most critical mechanism, where the Ser-3 residue of cofilin is the specific target. Roles of cofilin Cys-39 and Cys-147 residues are also becoming apparent in the context of ROS-induced rod formation in many neurodegenerative disorders. Newer studies report different molecular pathways of cofilin through which cofilin dysregulation and translocation in subcellular regions might be associated with various CNS disorders.

Recent advances in experimental techniques will significantly facilitate the understanding of the signaling pathways of cofilin function in development and disease conditions. Drugs or peptides targeting the critical amino acid residues of cofilin might be a new potential therapeutic strategy for neurodegenerative disorders.

Author Contributions: Conceptualization, J.N.N. and A.K.B. investigation, J.N.N. and A.K.B.; resources, J.N.N. and A.K.B.; writing-original draft preparation, J.N.N.; writing-review and editing, A.K.B. and H.T.; visualization, J.N.N. and A.K.B.; supervision, A.K.B. and H.T. All authors have read and agreed to the published version of the manuscript.

Funding: The APC was funded by a grant (21H02652) from the Japanese Ministry of Education, Culture, Sports, Science \& Technology (MEXT) to H.T.

Institutional Review Board Statement: Not applicable.

Informed Consent Statement: Not applicable.

Data Availability Statement: Not applicable.

Conflicts of Interest: The authors declare no conflict of interest. 


\section{References}

1. Pollard, T.D.; Borisy, G.G. Cellular Motility Driven by Assembly and Disassembly of Actin Filaments. Cell 2003, 112, $453-465$. [CrossRef]

2. Bamburg, J.R. Proteins of the ADF/Cofilin Family: Essential Regulators of Actin Dynamics. Annu. Rev. Cell Dev. Biol. 1999, 15, 185-230. [CrossRef] [PubMed]

3. Maciver, S.K.; Hussey, P.J. The ADF/Cofilin Family: Actin-Remodeling Proteins. Genome Biol. 2002, 3, reviews3007.1. [CrossRef] [PubMed]

4. Bamburg, J.R.; Harris, H.E.; Weeds, A.G. Partial Purification and Characterization of an Actin Depolymerizing Factor from Brain. FEBS Lett. 1980, 121, 178-182. [CrossRef]

5. Maekawa, S.; Nishida, E.; Ohta, Y.; Sakai, H. Isolation of Low Molecular Weight Actin-Binding Proteins from Porcine Brain1. J. Biochem. 1984, 95, 377-385. [CrossRef] [PubMed]

6. Nishida, E.; Maekawa, S.; Sakai, H. Cofilin, a Protein in Porcine Brain That Binds to Actin Filaments and Inhibits Their Interactions with Myosin and Tropomyosin. Biochemistry 1984, 23, 5307-5313. [CrossRef]

7. Ono, S.; Minami, N.; Abe, H.; Obinata, T. Characterization of a Novel Cofilin Isoform That Is Predominantly Expressed in Mammalian Skeletal Muscle. J. Biol. Chem. 1994, 269, 15280-15286. [CrossRef]

8. Blanchoin, L.; Pollard, T.D. Mechanism of Interaction of Acanthamoeba Actophorin (ADF/Cofilin) with Actin Filaments. J. Biol. Chem. 1999, 274, 15538-15546. [CrossRef]

9. Hayden, S.M.; Miller, P.S.; Brauweiler, A.; Bamburg, J.R. Analysis of the Interactions of Actin Depolymerizing Factor with G-and F-Actin. Biochemistry 1993, 32, 9994-10004. [CrossRef]

10. McGough, A.; Pope, B.; Chiu, W.; Weeds, A. Cofilin Changes the Twist of F-Actin: Implications for Actin Filament Dynamics and Cellular Function. J. Cell Biol. 1997, 138, 771-781. [CrossRef]

11. Minamide, L.S.; Striegl, A.M.; Boyle, J.A.; Meberg, P.J.; Bamburg, J.R. Neurodegenerative Stimuli Induce Persistent ADF/CofilinActin Rods That Disrupt Distal Neurite Function. Nat. Cell Biol. 2000, 2, 628-636. [CrossRef]

12. Carlier, M.F.; Laurent, V.; Santolini, J.; Melki, R.; Didry, D.; Xia, G.X.; Hong, Y.; Chua, N.H.; Pantaloni, D. Actin Depolymerizing Factor (ADF/Cofilin) Enhances the Rate of Filament Turnover: Implication in Actin-Based Motility. J. Cell Biol. 1997, 136, 1307-1322. [CrossRef]

13. Andrianantoandro, E.; Pollard, T.D. Mechanism of Actin Filament Turnover by Severing and Nucleation at Different Concentrations of ADF/Cofilin. Mol. Cell 2006, 24, 13-23. [CrossRef]

14. Galkin, V.E.; Orlova, A.; Kudryashov, D.S.; Solodukhin, A.; Reisler, E.; Schröder, G.F.; Egelman, E.H. Remodeling of Actin Filaments by ADF/Cofilin Proteins. Proc. Natl. Acad. Sci. USA 2011, 108, 20568-20572. [CrossRef]

15. De La Cruz, E.M. Cofilin Binding to Muscle and Non-Muscle Actin Filaments: Isoform-Dependent Cooperative Interactions. J. Mol. Biol. 2005, 346, 557-564. [CrossRef]

16. Wioland, H.; Guichard, B.; Senju, Y.; Myram, S.; Lappalainen, P.; Jégou, A.; Romet-Lemonne, G. ADF/Cofilin Accelerates Actin Dynamics by Severing Filaments and Promoting Their Depolymerization at Both Ends. Curr. Biol. 2017, 27, 1956-1967. [CrossRef]

17. Meyer, G.; Feldman, E.L. Signaling Mechanisms That Regulate Actin-based Motility Processes in the Nervous System. J. Neurochem. 2002, 83, 490-503. [CrossRef]

18. Samstag, Y.; John, I.; Wabnitz, G.H. Cofilin: A Redox Sensitive Mediator of Actin Dynamics during T-Cell Activation and Migration. Immunol. Rev. 2013, 256, 30-47. [CrossRef] [PubMed]

19. Marsick, B.M.; Flynn, K.C.; Santiago-Medina, M.; Bamburg, J.R.; Letourneau, P.C. Activation of ADF/Cofilin Mediates Attractive Growth Cone Turning toward Nerve Growth Factor and Netrin-1. Dev. Neurobiol. 2010, 70, 565-588. [CrossRef] [PubMed]

20. Meyer, G.; Kim, B.; van Golen, C.; Feldman, E.L. Cofilin Activity during Insulin-like Growth Factor I-Stimulated Neuroblastoma Cell Motility. Cell. Mol. Life Sci. 2005, 62, 461-470. [CrossRef] [PubMed]

21. Tilve, S.; Difato, F.; Chieregatti, E. Cofilin 1 Activation Prevents the Defects in Axon Elongation and Guidance Induced by Extracellular Alpha-Synuclein. Sci. Rep. 2015, 5, 16524. [CrossRef] [PubMed]

22. Bamburg, J.R.; Bernstein, B.W. Roles of ADF/Cofilin in Actin Polymerization and Beyond. F1000 Biol. Rep. 2010, 2. [CrossRef] [PubMed]

23. Huang, T.Y.; DerMardirossian, C.; Bokoch, G.M. Cofilin Phosphatases and Regulation of Actin Dynamics. Curr. Opin. Cell Biol. 2006, 18, 26-31. [CrossRef] [PubMed]

24. Mizuno, K. Signaling Mechanisms and Functional Roles of Cofilin Phosphorylation and Dephosphorylation. Cell. Signal. 2013, 25, 457-469. [CrossRef]

25. Ostrowska, Z.; Moraczewska, J. Cofilin-A Protein Controlling Dynamics of Actin Filaments. Postepy Hig. Med. Dosw. (Online) 2017, 71, 339-351. [CrossRef]

26. Sarmiere, P.D.; Bamburg, J.R. Regulation of the Neuronal Actin Cytoskeleton by ADF/Cofilin. J. Neurobiol. 2004, 58, 103-117. [CrossRef]

27. Van Troys, M.; Huyck, L.; Leyman, S.; Dhaese, S.; Vandekerkhove, J.; Ampe, C. Ins and Outs of ADF/Cofilin Activity and Regulation. Eur. J. Cell Biol. 2008, 87, 649-667. [CrossRef]

28. Klejnot, M.; Gabrielsen, M.; Cameron, J.; Mleczak, A.; Talapatra, S.K.; Kozielski, F.; Pannifer, A.; Olson, M.F. Analysis of the Human Cofilin 1 Structure Reveals Conformational Changes Required for Actin Binding. Acta Crystallogr. D Biol. Crystallogr. 2013, 69, 1780-1788. [CrossRef] 
29. Moriyama, K.; Iida, K.; Yahara, I. Phosphorylation of Ser-3 of Cofilin Regulates Its Essential Function on Actin. Genes Cells 1996, 1, 73-86. [CrossRef] [PubMed]

30. Niwa, R.; Nagata-Ohashi, K.; Takeichi, M.; Mizuno, K.; Uemura, T. Control of Actin Reorganization by Slingshot, a Family of Phosphatases That Dephosphorylate ADF/Cofilin. Cell 2002, 108, 233-246. [CrossRef]

31. Wang, Y.; Shibasaki, F.; Mizuno, K. Calcium Signal-Induced Cofilin Dephosphorylation Is Mediated by Slingshot via Calcineurin J. Biol. Chem. 2005, 280, 12683-12689. [CrossRef]

32. Arber, S.; Barbayannis, F.A.; Hanser, H.; Schneider, C.; Stanyon, C.A.; Bernard, O.; Caroni, P. Regulation of Actin Dynamics through Phosphorylation of Cofilin by LIM-Kinase. Nature 1998, 393, 805-809. [CrossRef]

33. Yang, N.; Higuchi, O.; Ohashi, K.; Nagata, K.; Wada, A.; Kangawa, K.; Nishida, E.; Mizuno, K. Cofilin Phosphorylation by LIM-Kinase 1 and Its Role in Rac-Mediated Actin Reorganization. Nature 1998, 393, 809-812. [CrossRef]

34. Kurita, S.; Gunji, E.; Ohashi, K.; Mizuno, K. Actin Filaments-stabilizing And-bundling Activities of Cofilin-phosphatase Slingshot1. Genes Cells 2007, 12, 663-676. [CrossRef]

35. Cai, L.; Marshall, T.W.; Uetrecht, A.C.; Schafer, D.A.; Bear, J.E. Coronin 1B Coordinates Arp2/3 Complex and Cofilin Activities at the Leading Edge. Cell 2007, 128, 915-929. [CrossRef]

36. Marshall, T.W.; Aloor, H.L.; Bear, J.E. Coronin 2A Regulates a Subset of Focal-Adhesion-Turnover Events through the Cofilin Pathway. J. Cell Sci. 2009, 122, 3061-3069. [CrossRef]

37. Nagata-Ohashi, K.; Ohta, Y.; Goto, K.; Chiba, S.; Mori, R.; Nishita, M.; Ohashi, K.; Kousaka, K.; Iwamatsu, A.; Niwa, R. A Pathway of Neuregulin-Induced Activation of Cofilin-Phosphatase Slingshot and Cofilin in Lamellipodia. J. Cell Biol. 2004, 165, 465-471. [CrossRef]

38. Yoon, B.C.; Zivraj, K.H.; Strochlic, L.; Holt, C.E. 14-3-3 Proteins Regulate Retinal Axon Growth by Modulating ADF/Cofilin Activity. Dev. Neurobiol. 2012, 72, 600-614. [CrossRef] [PubMed]

39. Eiseler, T.; Döppler, H.; Yan, I.K.; Kitatani, K.; Mizuno, K.; Storz, P. Protein Kinase D1 Regulates Cofilin-Mediated F-Actin Reorganization and Cell Motility through Slingshot. Nat. Cell Biol. 2009, 11, 545-556. [CrossRef]

40. Kim, J.-E.; Ryu, H.J.; Kim, M.-J.; Kim, D.-W.; Kwon, O.-S.; Choi, S.Y.; Kang, T.-C. Pyridoxal-5'-Phosphate Phosphatase/Chronophin Induces Astroglial Apoptosis via Actin-Depolymerizing Factor/Cofilin System in the Rat Brain Following Status Epilepticus. Glia 2010, 58, 1937-1948. [CrossRef]

41. Kim, J.-E.; Kim, D.-W.; Kwak, S.-E.; Kwon, O.-S.; Choi, S.-Y.; Kang, T.-C. Potential Role of Pyridoxal-5'-Phosphate Phosphatase/Chronopin in Epilepsy. Exp. Neurol. 2008, 211, 128-140. [CrossRef]

42. Medina, C.; de la Fuente, V.; Tom Dieck, S.; Nassim-Assir, B.; Dalmay, T.; Bartnik, I.; Lunardi, P.; de Oliveira Alvares, L.; Schuman, E.M.; Letzkus, J.J.; et al. LIMK, Cofilin 1 and Actin Dynamics Involvement in Fear Memory Processing. Neurobiol. Learn Mem. 2020, 173, 107275. [CrossRef]

43. Dan, C.; Kelly, A.; Bernard, O.; Minden, A. Cytoskeletal Changes Regulated by the PAK4 Serine/Threonine Kinase Are Mediated by LIM Kinase 1 and Cofilin. J. Biol. Chem. 2001, 276, 32115-32121. [CrossRef]

44. Toshima, J.; Toshima, J.Y.; Amano, T.; Yang, N.; Narumiya, S.; Mizuno, K. Cofilin Phosphorylation by Protein Kinase Testicular Protein Kinase 1 and Its Role in Integrin-Mediated Actin Reorganization and Focal Adhesion Formation. MBoC 2001, 12, 1131-1145. [CrossRef]

45. Toshima, J.; Toshima, J.Y.; Takeuchi, K.; Mori, R.; Mizuno, K. Cofilin Phosphorylation and Actin Reorganization Activities of Testicular Protein Kinase 2 and Its Predominant Expression in Testicular Sertoli Cells. J. Biol. Chem. 2001, 276, 31449-31458. [CrossRef]

46. Chai, X.; Förster, E.; Zhao, S.; Bock, H.H.; Frotscher, M. Reelin Stabilizes the Actin Cytoskeleton of Neuronal Processes by Inducing N-Cofilin Phosphorylation at Serine3. J. Neurosci. 2009, 29, 288-299. [CrossRef] [PubMed]

47. Krüger, M.T.; Zhao, S.; Chai, X.; Brunne, B.; Bouché, E.; Bock, H.H.; Frotscher, M. Role for Reelin-Induced Cofilin Phosphorylation in the Assembly of Sympathetic Preganglionic Neurons in the Murine Intermediolateral Column. Eur. J. Neurosci. 2010, 32, 1611-1617. [CrossRef] [PubMed]

48. Cho, I.H.; Lee, M.J.; Kim, D.H.; Kim, B.; Bae, J.; Choi, K.Y.; Kim, S.-M.; Huh, Y.H.; Lee, K.H.; Kim, C.-H.; et al. SPIN90 Dephosphorylation Is Required for Cofilin-Mediated Actin Depolymerization in NMDA-Stimulated Hippocampal Neurons. Cell Mol. Life Sci. 2013, 70, 4369-4383. [CrossRef]

49. Oser, M.; Yamaguchi, H.; Mader, C.C.; Bravo-Cordero, J.J.; Arias, M.; Chen, X.; Desmarais, V.; van Rheenen, J.; Koleske, A.J.; Condeelis, J. Cortactin Regulates Cofilin and N-WASp Activities to Control the Stages of Invadopodium Assembly and Maturation. J. Cell Biol. 2009, 186, 571-587. [CrossRef]

50. Kotila, T.; Wioland, H.; Enkavi, G.; Kogan, K.; Vattulainen, I.; Jégou, A.; Romet-Lemonne, G.; Lappalainen, P. Mechanism of Synergistic Actin Filament Pointed End Depolymerization by Cyclase-Associated Protein and Cofilin. Nat. Commun. 2019, 10, 5320. [CrossRef]

51. Endo, M.; Ohashi, K.; Sasaki, Y.; Goshima, Y.; Niwa, R.; Uemura, T.; Mizuno, K. Control of Growth Cone Motility and Morphology by LIM Kinase and Slingshot via Phosphorylation and Dephosphorylation of Cofilin. J. Neurosci. 2003, 23, 2527-2537. [CrossRef]

52. Kurita, S.; Watanabe, Y.; Gunji, E.; Ohashi, K.; Mizuno, K. Molecular Dissection of the Mechanisms of Substrate Recognition and F-Actin-Mediated Activation of Cofilin-Phosphatase Slingshot-1. J. Biol. Chem. 2008, 283, 32542-32552. [CrossRef] 
53. Soosairajah, J.; Maiti, S.; Wiggan, O.; Sarmiere, P.; Moussi, N.; Sarcevic, B.; Sampath, R.; Bamburg, J.R.; Bernard, O. Interplay between Components of a Novel LIM Kinase-Slingshot Phosphatase Complex Regulates Cofilin. EMBO J. 2005, 24, $473-486$. [CrossRef]

54. Singla, B.; Lin, H.-P.; Ghoshal, P.; Cherian-Shaw, M.; Csányi, G. PKC $\delta$ Stimulates Macropinocytosis via Activation of SSH1-Cofilin Pathway. Cell. Signal. 2019, 53, 111-121. [CrossRef] [PubMed]

55. Wang, W.; Halasz, E.; Townes-Anderson, E. Actin Dynamics, Regulated by RhoA-LIMK-Cofilin Signaling, Mediates Rod Photoreceptor Axonal Retraction After Retinal Injury. Invest. Ophthalmol. Vis. Sci. 2019, 60, 2274-2285. [CrossRef]

56. Lou, D.; Sun, B.; Wei, H.; Deng, X.; Chen, H.; Xu, D.; Li, G.; Xu, H.; Wang, Y. Spatiotemporal Expression of Testicular Protein Kinase 1 after Rat Sciatic Nerve Injury. J. Mol. Neurosci. 2012, 47, 180-191. [CrossRef] [PubMed]

57. Wang, L.; Buckley, A.F.; Spurney, R.F. Regulation of Cofilin Phosphorylation in Glomerular Podocytes by Testis Specific Kinase 1 (TESK1). Sci. Rep. 2018, 8, 12286. [CrossRef] [PubMed]

58. Ono, S. The Role of Cyclase-Associated Protein in Regulating Actin Filament Dynamics-More than a Monomer-Sequestration Factor. J. Cell Sci. 2013, 126, 3249-3258. [CrossRef] [PubMed]

59. Peche, V.; Shekar, S.; Leichter, M.; Korte, H.; Schröder, R.; Schleicher, M.; Holak, T.A.; Clemen, C.S.; Ramanath-Y, B.; Pfitzer, G.; et al. CAP2, Cyclase-Associated Protein 2, Is a Dual Compartment Protein. Cell Mol. Life Sci. 2007, 64, 2702-2715. [CrossRef]

60. Kumar, A.; Paeger, L.; Kosmas, K.; Kloppenburg, P.; Noegel, A.A.; Peche, V.S. Neuronal Actin Dynamics, Spine Density and Neuronal Dendritic Complexity Are Regulated by CAP2. Front. Cell. Neurosci. 2016, 10. [CrossRef]

61. Cameron, J.M.; Gabrielsen, M.; Chim, Y.H.; Munro, J.; McGhee, E.J.; Sumpton, D.; Eaton, P.; Anderson, K.I.; Yin, H.; Olson, M.F. Polarized Cell Motility Induces Hydrogen Peroxide to Inhibit Cofilin via Cysteine Oxidation. Curr. Biol. 2015, 25, 1520-1525. [CrossRef]

62. Bernstein, B.W.; Shaw, A.E.; Minamide, L.S.; Pak, C.W.; Bamburg, J.R. Incorporation of Cofilin into Rods Depends on Disulfide Intermolecular Bonds: Implications for Actin Regulation and Neurodegenerative Disease. J. Neurosci. 2012, 32, 6670-6681. [CrossRef]

63. Pfannstiel, J.; Cyrklaff, M.; Habermann, A.; Stoeva, S.; Griffiths, G.; Shoeman, R.; Faulstich, H. Human Cofilin Forms Oligomers Exhibiting Actin Bundling Activity. J. Biol. Chem. 2001, 276, 49476-49484. [CrossRef]

64. Yuskaitis, C.J.; Pomeroy, S.L. Development of the Nervous System. In Fetal and Neonatal Physiology; Elsevier: Philadelphia, PA, USA, 2017; pp. 1294-1313.e2. ISBN 978-0-323-35214-7.

65. Esteves, M.; Almeida, A.; Leite-Almeida, H. Insights on nervous system biology and anatomy. In Handbook of Innovations in Central Nervous System Regenerative Medicine; Elsevier: Philadelphia, PA, USA, 2020; pp. 1-28. ISBN 978-0-12-818084-6.

66. Gurniak, C.B.; Perlas, E.; Witke, W. The Actin Depolymerizing Factor N-Cofilin Is Essential for Neural Tube Morphogenesis and Neural Crest Cell Migration. Dev. Biol. 2005, 278, 231-241. [CrossRef]

67. Escuin, S.; Vernay, B.; Savery, D.; Gurniak, C.B.; Witke, W.; Greene, N.D.E.; Copp, A.J. Rho-Kinase-Dependent Actin Turnover and Actomyosin Disassembly Are Necessary for Mouse Spinal Neural Tube Closure. J. Cell Sci. 2015, 128, 2468-2481. [CrossRef] [PubMed]

68. Grego-Bessa, J.; Hildebrand, J.; Anderson, K.V. Morphogenesis of the Mouse Neural Plate Depends on Distinct Roles of Cofilin 1 in Apical and Basal Epithelial Domains. Development 2015, 142, 1305-1314. [CrossRef] [PubMed]

69. Brown, J.M.; García-García, M.J. Secretory Pathway Calcium ATPase 1 (SPCA1) Controls Mouse Neural Tube Closure by Regulating Cytoskeletal Dynamics. Development 2018, 145. [CrossRef] [PubMed]

70. Dent, E.W.; Kalil, K. Axon Branching Requires Interactions between Dynamic Microtubules and Actin Filaments. J. Neurosci. 2001, 21, 9757-9769. [CrossRef]

71. Mallavarapu, A.; Mitchison, T. Regulated Actin Cytoskeleton Assembly at Filopodium Tips Controls Their Extension and Retraction. J. Cell Biol. 1999, 146, 1097-1106. [CrossRef]

72. Star, E.N.; Kwiatkowski, D.J.; Murthy, V.N. Rapid Turnover of Actin in Dendritic Spines and Its Regulation by Activity. Nat. Neurosci. 2002, 5, 239-246. [CrossRef]

73. Fass, J.; Gehler, S.; Sarmiere, P.; Letourneau, P.; Bamburg, J.R. Regulating Filopodial Dynamics through Actin-Depolymerizing Factor/Cofilin. Anato. Sci. Int. 2004, 79, 173. [CrossRef] [PubMed]

74. Aizawa, H.; Wakatsuki, S.; Ishii, A.; Moriyama, K.; Sasaki, Y.; Ohashi, K.; Sekine-Aizawa, Y.; Sehara-Fujisawa, A.; Mizuno, K.; Goshima, Y. Phosphorylation of Cofilin by LIM-Kinase Is Necessary for Semaphorin 3A-Induced Growth Cone Collapse. Nat. Neurosci. 2001, 4, 367-373. [CrossRef]

75. Montani, L.; Gerrits, B.; Gehrig, P.; Kempf, A.; Dimou, L.; Wollscheid, B.; Schwab, M.E. Neuronal Nogo-A Modulates Growth Cone Motility via Rho-GTP/LIMK1/Cofilin in the Unlesioned Adult Nervous System. J. Biol. Chem. 2009, $284,10793-10807$. [CrossRef] [PubMed]

76. Flynn, K.C.; Hellal, F.; Neukirchen, D.; Jacob, S.; Tahirovic, S.; Dupraz, S.; Stern, S.; Garvalov, B.K.; Gurniak, C.; Shaw, A.E. ADF/Cofilin-Mediated Actin Retrograde Flow Directs Neurite Formation in the Developing Brain. Neuron 2012, 76, 1091-1107. [CrossRef] [PubMed]

77. Flynn, K.C.; Pak, C.W.; Shaw, A.E.; Bradke, F.; Bamburg, J.R. Growth Cone-like Waves Transport Actin and Promote Axonogenesis and Neurite Branching. Dev. Neurobiol. 2009, 69, 761-779. [CrossRef] [PubMed]

78. Cingolani, L.A.; Goda, Y. Actin in Action: The Interplay between the Actin Cytoskeleton and Synaptic Efficacy. Nat. Rev. Neurosci. 2008, 9, 344-356. [CrossRef] [PubMed] 
79. Bosch, M.; Castro, J.; Saneyoshi, T.; Matsuno, H.; Sur, M.; Hayashi, Y. Structural and Molecular Remodeling of Dendritic Spine Substructures during Long-Term Potentiation. Neuron 2014, 82, 444-459. [CrossRef]

80. Rex, C.S.; Chen, L.Y.; Sharma, A.; Liu, J.; Babayan, A.H.; Gall, C.M.; Lynch, G. Different Rho GTPase-Dependent Signaling Pathways Initiate Sequential Steps in the Consolidation of Long-Term Potentiation. J. Cell Biol. 2009, 186, 85-97. [CrossRef]

81. Gu, J.; Lee, C.W.; Fan, Y.; Komlos, D.; Tang, X.; Sun, C.; Yu, K.; Hartzell, H.C.; Chen, G.; Bamburg, J.R. ADF/Cofilin-Mediated Actin Dynamics Regulate AMPA Receptor Trafficking during Synaptic Plasticity. Nat. Neurosci. 2010, 13, 1208. [CrossRef]

82. Rust, M.B.; Gurniak, C.B.; Renner, M.; Vara, H.; Morando, L.; Görlich, A.; Sassoè-Pognetto, M.; Banchaabouchi, M.A.; Giustetto, M.; Triller, A. Learning, AMPA Receptor Mobility and Synaptic Plasticity Depend on N-cofilin-mediated Actin Dynamics. EMBO J. 2010, 29, 1889-1902. [CrossRef]

83. Zhou, Q.; Homma, K.J.; Poo, M. Shrinkage of Dendritic Spines Associated with Long-Term Depression of Hippocampal Synapses. Neuron 2004, 44, 749-757. [CrossRef]

84. Malinow, R.; Malenka, R.C. AMPA Receptor Trafficking and Synaptic Plasticity. Annu. Rev. Neurosci. 2002, 25, 103-126. [CrossRef]

85. Wang, Y.; Dong, Q.; Xu, X.-F.; Feng, X.; Xin, J.; Wang, D.-D.; Yu, H.; Tian, T.; Chen, Z.-Y. Phosphorylation of Cofilin Regulates Extinction of Conditioned Aversive Memory via AMPAR Trafficking. J. Neurosci. 2013, 33, 6423-6433. [CrossRef]

86. Hilton, B.J.; Bradke, F. Can Injured Adult CNS Axons Regenerate by Recapitulating Development? Development 2017, 144, 3417-3429. [CrossRef]

87. Saxena, S.; Caroni, P. Mechanisms of Axon Degeneration: From Development to Disease. Prog. Neurobiol. 2007, 83, 174-191. [CrossRef]

88. Hill, C.E.; Beattie, M.S.; Bresnahan, J.C. Degeneration and Sprouting of Identified Descending Supraspinal Axons after Contusive Spinal Cord Injury in the Rat. Exp. Neurol. 2001, 171, 153-169. [CrossRef]

89. Stern, S.; Haverkamp, S.; Sinske, D.; Tedeschi, A.; Naumann, U.; Giovanni, S.D.; Kochanek, S.; Nordheim, A.; Knöll, B. The Transcription Factor Serum Response Factor Stimulates Axon Regeneration through Cytoplasmic Localization and Cofilin Interaction. J. Neurosci. 2013, 33, 18836-18848. [CrossRef] [PubMed]

90. Ahmed, Z.; Douglas, M.R.; Read, M.L.; Berry, M.; Logan, A. Citron Kinase Regulates Axon Growth through a Pathway That Converges on Cofilin Downstream of RhoA. Neurobiol. Dis. 2011, 41, 421-429. [CrossRef] [PubMed]

91. Tedeschi, A.; Dupraz, S.; Curcio, M.; Laskowski, C.J.; Schaffran, B.; Flynn, K.C.; Santos, T.E.; Stern, S.; Hilton, B.J.; Larson, M.J.E.; et al. ADF/Cofilin-Mediated Actin Turnover Promotes Axon Regeneration in the Adult CNS. Neuron 2019, 103, 1073-1085.e6. [CrossRef] [PubMed]

92. Wolf, M.; Zimmermann, A.-M.; Görlich, A.; Gurniak, C.B.; Sassoè-Pognetto, M.; Friauf, E.; Witke, W.; Rust, M.B. ADF/Cofilin Controls Synaptic Actin Dynamics and Regulates Synaptic Vesicle Mobilization and Exocytosis. Cereb Cortex 2015, 25, $2863-2875$. [CrossRef]

93. Heredia, L.; Helguera, P.; de Olmos, S.; Kedikian, G.; Vigo, F.S.; LaFerla, F.; Staufenbiel, M.; de Olmos, J.; Busciglio, J.; Cáceres, A.; et al. Phosphorylation of Actin-Depolymerizing Factor/Cofilin by LIM-Kinase Mediates Amyloid $\beta$-Induced Degeneration: A Potential Mechanism of Neuronal Dystrophy in Alzheimer's Disease. J. Neurosci. 2006, 26, 6533-6542. [CrossRef] [PubMed]

94. Maloney, M.T.; Minamide, L.S.; Kinley, A.W.; Boyle, J.A.; Bamburg, J.R. Beta-Secretase-Cleaved Amyloid Precursor Protein Accumulates at Actin Inclusions Induced in Neurons by Stress or Amyloid Beta: A Feedforward Mechanism for Alzheimer's Disease. J. Neurosci. 2005, 25, 11313-11321. [CrossRef] [PubMed]

95. Walsh, K.P.; Minamide, L.S.; Kane, S.J.; Shaw, A.E.; Brown, D.R.; Pulford, B.; Zabel, M.D.; Lambeth, J.D.; Kuhn, T.B.; Bamburg, J.R. Amyloid- $\beta$ and Proinflammatory Cytokines Utilize a Prion Protein-Dependent Pathway to Activate NADPH Oxidase and Induce Cofilin-Actin Rods in Hippocampal Neurons. PLoS ONE 2014, 9, e95995. [CrossRef] [PubMed]

96. Nussbaum, J.M.; Seward, M.E.; Bloom, G.S. Alzheimer Disease: A Tale of Two Prions. Prion 2013, 7, 14-19. [CrossRef]

97. Querfurth, H.W.; LaFerla, F.M. Alzheimer's Disease. N. Engl. J. Med. 2010, 362, 329-344. [CrossRef]

98. Terry, R.D.; Masliah, E.; Salmon, D.P.; Butters, N.; DeTeresa, R.; Hill, R.; Hansen, L.A.; Katzman, R. Physical Basis of Cognitive Alterations in Alzheimer's Disease: Synapse Loss Is the Major Correlate of Cognitive Impairment. Ann. Neurol. Off. J. Am. Neurol. Assoc. Child Neurol. Soc. 1991, 30, 572-580. [CrossRef]

99. Rahman, T.; Davies, D.S.; Tannenberg, R.K.; Fok, S.; Shepherd, C.; Dodd, P.R.; Cullen, K.M.; Goldsbury, C. Cofilin Rods and Aggregates Concur with Tau Pathology and the Development of Alzheimer's Disease. J. Alzheimers Dis. 2014, 42, 1443-1460. [CrossRef] [PubMed]

100. Woo, J.A.; Zhao, X.; Khan, H.; Penn, C.; Wang, X.; Joly-Amado, A.; Weeber, E.; Morgan, D.; Kang, D.E. Slingshot-Cofilin Activation Mediates Mitochondrial and Synaptic Dysfunction via A $\beta$ Ligation to B1-Integrin Conformers. Cell Death Differ. 2015, 22, 921-934. [CrossRef]

101. Woo, J.A.; Boggess, T.; Uhlar, C.; Wang, X.; Khan, H.; Cappos, G.; Joly-Amado, A.; De Narvaez, E.; Majid, S.; Minamide, L.S.; et al. RanBP9 at the Intersection between Cofilin and A $\beta$ Pathologies: Rescue of Neurodegenerative Changes by RanBP9 Reduction. Cell Death Dis. 2015, 6, 1676. [CrossRef] [PubMed]

102. Woo, J.A.; Jung, A.R.; Lakshmana, M.K.; Bedrossian, A.; Lim, Y.; Bu, J.H.; Park, S.A.; Koo, E.H.; Mook-Jung, I.; Kang, D.E. Pivotal Role of the RanBP9-Cofilin Pathway in A $\beta$-Induced Apoptosis and Neurodegeneration. Cell Death Differ. 2012, 19, $1413-1423$. [CrossRef] 
103. Whiteman, I.T.; Gervasio, O.L.; Cullen, K.M.; Guillemin, G.J.; Jeong, E.V.; Witting, P.K.; Antao, S.T.; Minamide, L.S.; Bamburg, J.R.; Goldsbury, C. Activated Actin-Depolymerizing Factor/Cofilin Sequesters Phosphorylated Microtubule-Associated Protein during the Assembly of Alzheimer-like Neuritic Cytoskeletal Striations. J. Neurosci. 2009, 29, 12994-13005. [CrossRef]

104. Woo, J.-A.A.; Liu, T.; Fang, C.C.; Cazzaro, S.; Kee, T.; LePochat, P.; Yrigoin, K.; Penn, C.; Zhao, X.; Wang, X.; et al. Activated Cofilin Exacerbates Tau Pathology by Impairing Tau-Mediated Microtubule Dynamics. Commun. Biol. 2019, 2, 112. [CrossRef]

105. Yoshiyama, Y.; Higuchi, M.; Zhang, B.; Huang, S.-M.; Iwata, N.; Saido, T.C.; Maeda, J.; Suhara, T.; Trojanowski, J.Q.; Lee, V.M.-Y. Synapse Loss and Microglial Activation Precede Tangles in a P301S Tauopathy Mouse Model. Neuron 2007, 53, 337-351. [CrossRef]

106. Yang, T.; Liu, H.; Tran, K.C.; Leng, A.; Massa, S.M.; Longo, F.M. Small-Molecule Modulation of the P75 Neurotrophin Receptor Inhibits a Wide Range of Tau Molecular Pathologies and Their Sequelae in P301S Tauopathy Mice. Acta Neuropathol. Commun. 2020, 8, 156. [CrossRef]

107. Pelucchi, S.; Vandermeulen, L.; Pizzamiglio, L.; Aksan, B.; Yan, J.; Konietzny, A.; Bonomi, E.; Borroni, B.; Padovani, A.; Rust, M.B.; et al. Cyclase-Associated Protein 2 Dimerization Regulates Cofilin in Synaptic Plasticity and Alzheimer's Disease. Brain Commun. 2020, 2. [CrossRef] [PubMed]

108. Joyce, E.M.; Roiser, J.P. Cognitive Heterogeneity in Schizophrenia. Curr. Opin. Psychiatry 2007, 20, 268. [CrossRef] [PubMed]

109. Owen, M.J.; Sawa, A.; Mortensen, P.B. Schizophrenia. Lancet 2016, 388, 86-97. [CrossRef]

110. Hill, J.J.; Hashimoto, T.; Lewis, D.A. Molecular Mechanisms Contributing to Dendritic Spine Alterations in the Prefrontal Cortex of Subjects with Schizophrenia. Mol. Psychiatry 2006, 11, 557-566. [CrossRef]

111. Ide, M.; Lewis, D.A. Altered Cortical CDC42 Signaling Pathways in Schizophrenia: Implications for Dendritic Spine Deficits. Biol. Psychiatry 2010, 68, 25-32. [CrossRef]

112. Hachisuka, A.; Nakajima, O.; Yamazaki, T.; Sawada, J. Developmental Expression of Opioid-Binding Cell Adhesion Molecule (OBCAM) in Rat Brain. Dev. Brain Res. 2000, 122, 183-191. [CrossRef]

113. Schol-Gelok, S.; Janssens, A.C.J.; Tiemeier, H.; Liu, F.; Lopez-Leon, S.; Zorkoltseva, I.V.; Axenovich, T.I.; van Swieten, J.C.; Uitterlinden, A.G.; Hofman, A. A Genome-Wide Screen for Depression in Two Independent Dutch Populations. Biol. Psychiatry 2010, 68, 187-196. [CrossRef]

114. Zhang, Z.; Ye, M.; Li, Q.; You, Y.; Yu, H.; Ma, Y.; Mei, L.; Sun, X.; Wang, L.; Yue, W. The Schizophrenia Susceptibility Gene OPCML Regulates Spine Maturation and Cognitive Behaviors through Eph-Cofilin Signaling. Cell Rep. 2019, 29, 49-61. [CrossRef]

115. Foote, M.; Qiao, H.; Graham, K.; Wu, Y.; Zhou, Y. Inhibition of 14-3-3 Proteins Leads to Schizophrenia-Related Behavioral Phenotypes and Synaptic Defects in Mice. Biol. Psychiatry 2015, 78, 386-395. [CrossRef]

116. Dirnagl, U.; Iadecola, C.; Moskowitz, M.A. Pathobiology of Ischaemic Stroke: An Integrated View. Trends Neurosci. 1999, 22, 391-397. [CrossRef]

117. Wang, Y.; Qin, Z.-H. Molecular and Cellular Mechanisms of Excitotoxic Neuronal Death. Apoptosis 2010, 15, 1382-1402. [CrossRef] [PubMed]

118. Mabuchi, T.; Kitagawa, K.; Kuwabara, K.; Takasawa, K.; Ohtsuki, T.; Xia, Z.; Storm, D.; Yanagihara, T.; Hori, M.; Matsumoto, M. Phosphorylation of CAMP Response Element-Binding Protein in Hippocampal Neurons as a Protective Response after Exposure to Glutamate in Vitro and Ischemia in Vivo. J. Neurosci. 2001, 21, 9204-9213. [CrossRef] [PubMed]

119. Chen, B.; Jiang, M.; Zhou, M.; Chen, L.; Liu, X.; Wang, X.; Wang, Y. Both NMDA and Non-NMDA Receptors Mediate Glutamate Stimulation Induced Cofilin Rod Formation in Cultured Hippocampal Neurons. Brain Res. 2012, 1486, 1-13. [CrossRef]

120. Shu, L.; Chen, B.; Chen, B.; Xu, H.; Wang, G.; Huang, Y.; Zhao, Y.; Gong, H.; Jiang, M.; Chen, L.; et al. Brain Ischemic Insult Induces Cofilin Rod Formation Leading to Synaptic Dysfunction in Neurons. J. Cereb. Blood Flow Metab. 2019, 39, $2181-2195$. [CrossRef] [PubMed]

121. Won, S.J.; Minnella, A.M.; Wu, L.; Eun, C.H.; Rome, E.; Herson, P.S.; Shaw, A.E.; Bamburg, J.R.; Swanson, R.A. Cofilin-Actin Rod Formation in Neuronal Processes after Brain Ischemia. PLoS ONE 2018, 13, e0198709. [CrossRef]

122. Posadas, I.; Pérez-Martínez, F.C.; Guerra, J.; Sánchez-Verdú, P.; Ceña, V. Cofilin Activation Mediates Bax Translocation to Mitochondria during Excitotoxic Neuronal Death. J. Neurochem. 2012, 120, 515-527. [CrossRef]

123. Chen, B.; Lin, W.; Qi, W.; Li, S.; Hong, Z.; Zhao, H. Cofilin Inhibition by Limk1 Reduces Rod Formation and Cell Apoptosis after Ischemic Stroke. Neuroscience 2020, 444, 64-75. [CrossRef]

124. Juurlink, B.H.; Thorburne, S.K.; Hertz, L. Peroxide-scavenging Deficit Underlies Oligodendrocyte Susceptibility to Oxidative Stress. Glia 1998, 22, 371-378. [CrossRef]

125. Wabnitz, G.H.; Goursot, C.; Jahraus, B.; Kirchgessner, H.; Hellwig, A.; Klemke, M.; Konstandin, M.H.; Samstag, Y. Mitochondrial Translocation of Oxidized Cofilin Induces Caspase-Independent Necrotic-like Programmed Cell Death of T Cells. Cell Death Dis. 2010, 1, e58. [CrossRef]

126. Alhadidi, Q.; Bin Sayeed, M.S.; Shah, Z.A. Cofilin as a Promising Therapeutic Target for Ischemic and Hemorrhagic Stroke. Transl. Stroke Res. 2016, 7, 33-41. [CrossRef] [PubMed]

127. Kim, J.Y.; Han, Y.; Lee, J.E.; Yenari, M.A. The 70-KDa Heat Shock Protein (Hsp70) as a Therapeutic Target for Stroke. Expert Opin. Ther. Targets 2018, 22, 191-199. [CrossRef] [PubMed]

128. Kurisu, K.; You, J.; Zheng, Z.; Won, S.J.; Swanson, R.A.; Yenari, M.A. Cofilin-Actin Rod Formation in Experimental Stroke Is Attenuated by Therapeutic Hypothermia and Overexpression of the Inducible 70 KD Inducible Heat Shock Protein (Hsp70). Brain Circ. 2019, 5, 225-233. [CrossRef] [PubMed] 
129. Li, J.-Y.; Englund, E.; Widner, H.; Rehncrona, S.; Björklund, A.; Lindvall, O.; Brundin, P. Characterization of Lewy Body Pathology in 12- and 16-Year-Old Intrastriatal Mesencephalic Grafts Surviving in a Patient with Parkinson's Disease. Mov. Disord. 2010, 25, 1091-1096. [CrossRef] [PubMed]

130. Ibáñez, P.; Bonnet, A.-M.; Débarges, B.; Lohmann, E.; Tison, F.; Agid, Y.; Dürr, A.; Brice, A.; Pollak, P. Causal Relation between $\alpha$-Synuclein Locus Duplication as a Cause of Familial Parkinson's Disease. Lancet 2004, 364, 1169-1171. [CrossRef]

131. Emmanouilidou, E.; Melachroinou, K.; Roumeliotis, T.; Garbis, S.D.; Ntzouni, M.; Margaritis, L.H.; Stefanis, L.; Vekrellis, K. Cell-Produced $\alpha$-Synuclein Is Secreted in a Calcium-Dependent Manner by Exosomes and Impacts Neuronal Survival. J. Neurosci. 2010, 30, 6838-6851. [CrossRef] [PubMed]

132. Bellani, S.; Mescola, A.; Ronzitti, G.; Tsushima, H.; Tilve, S.; Canale, C.; Valtorta, F.; Chieregatti, E. GRP78 Clustering at the Cell Surface of Neurons Transduces the Action of Exogenous Alpha-Synuclein. Cell Death Differ. 2014, 21, 1971-1983. [CrossRef]

133. Yan, M.; Meng, L.; Dai, L.; Zhang, X.; Chen, G.; Zheng, Y.; Zha, Y.; Zeng, Y.; Zhang, Z. Cofilin 1 Promotes the Aggregation and Cell-to-Cell Transmission of $\alpha$-Synuclein in Parkinson's Disease. Biochem. Biophys. Res. Commun. 2020, 529, 1053-1060. [CrossRef]

134. Zhong, Z.; Grasso, L.; Sibilla, C.; Stevens, T.J.; Barry, N.; Bertolotti, A. Prion-like Protein Aggregates Exploit the RHO GTPase to Cofilin-1 Signaling Pathway to Enter Cells. EMBO J. 2018, 37. [CrossRef] [PubMed]

135. Kitada, T.; Asakawa, S.; Hattori, N.; Matsumine, H.; Yamamura, Y.; Minoshima, S.; Yokochi, M.; Mizuno, Y.; Shimizu, N. Mutations in the Parkin Gene Cause Autosomal Recessive Juvenile Parkinsonism. Nature 1998, 392, 605-608. [CrossRef] [PubMed]

136. Periquet, M.; Latouche, M.; Lohmann, E.; Rawal, N.; De Michele, G.; Ricard, S.; Teive, H.; Fraix, V.; Vidailhet, M.; Nicholl, D.; et al. Parkin Mutations Are Frequent in Patients with Isolated Early-onset Parkinsonism. Brain 2003, 126, 1271-1278. [CrossRef] [PubMed]

137. Lim, M.K.; Kawamura, T.; Ohsawa, Y.; Ohtsubo, M.; Asakawa, S.; Takayanagi, A.; Shimizu, N. Parkin Interacts with LIM Kinase 1 and Reduces Its Cofilin-Phosphorylation Activity via Ubiquitination. Exp. Cell Res. 2007, 313, 2858-2874. [CrossRef] 